\title{
Biocontrol of Mycoflora of Winter Wheat Seeds
}

\author{
Sergey Pospelov*, Anna Pospelova, Ninel Kovalenko, Elena Sherstiuk, Viacheslav Zdor \\ Poltava State Agrarian Academy, 36003, st. Skovorody 1/3 Poltava, Ukraine
}

\begin{abstract}
Absract. Presented are the experimental data on the effect of biofungicides on seed infection and mycoflora of winter wheat seeds of varieties 'Levada' and 'Podolyanka'. The phytostudy which was conducted allowed to determine the presence of micromycetes such as Alternaria alternata (infection rate 6.8-19.5\%), Tilletia caries (1-2\%), Fusarium spp. (0.5-3.5\%), Cladosporium herbarum (1.5-3.5\%), Bipolaris sorokiniana (1.0-4.8\%), Mucor spp. (1.5-12\%), Penicillium spp. (0.5$1.5 \%$ ), and Aspergillus spp. (1-1.5\%) on the seeds. The trend to decrease laboratory germination and lower infection rate was observed after the seeds were treated with biofungicides Gaubsin, Planriz, and Trichodermin. The positive effect of the biofungicides on the morphometric parameters of two-weeks-old plants was observed: 1.6 to 2 times increase in height, 2.1 to 2.8 times increase in the lengths of the roots, and 2.7 to 4.4 and 3.4 to 5.5 times increase in phytomass, respectively. The positive effect of Trichodermin on developing winter wheat plants was noted.
\end{abstract}

\section{Introduction}

Due to a decrease in biodiversity of soil microflora and an increase in the anthropogenic load on the soil, fewer natural barriers to seed infection arise [1-5]. Therefore, seed treatment is an important technique in modern agricultural technologies for growing the majority of crops [6]. At the same time, the number of manufacturers of environmentallyfriendly products is steadily increasing. It necessitates the search for substances of biological origin to be used to reduce the harmfulness of diseases, stimulate the growth and development of the plants [3]. For this reason, the biofungicides of bacterial (Planriz and Gaubsin) and fungal origin (Trichodermin) are studied in depth. Planriz (based on Pseudomonas ssp.) has fungicidal activity and has been studied in field and vegetable crops and in floriculture [7]. Gaubsin (based on Bacillus ssp.) is used for treatment of bacterial and fungal diseases in fruit, vegetable and field crops. It also inhibits the development of viral infections $[2,4]$. Trichodermin (based on Trichoderma ssp.) is a promising agent that utilizes the mechanisms of mycoparasitism, antagonism and competitiveness for resources. It not only increases a plant's resistance to diseases, but also increases its productivity $[8,9]$.

The objectives of our research were to conduct a phytostudy of winter wheat seeds and to determine the effectiveness of biofungicides for seed infection control and the morphometric parameters of plants after the seed treatment.

\footnotetext{
${ }^{*}$ Corresponding author : sergii.pospielov@pdaa.edu.ua
} 


\section{Materials and Methods}

The objects of the study included winter wheat seeds of 'Levada' and 'Podolyanka' varieties and biofungicides Trichodermin, Planriz and Gaubsin. Raksil Utra, FS a chemical fungicide, was used as a standard of treatment. The sowing qualities of seeds and contaminationby microorganisms were determined in accordance with DSTU 4138-2002 and DSTU 2240-93 [10, 11]. The degree of seed infection in the samples was expressed as a percentage of the total number of analyzed seeds (from 100 seeds). The determination of the species composition of fungi was done by microscopy using the crushed drop method at a magnification of $40 \times 10$. The study of biofungicides was performed in accordance with C.O. Tribel's methodology of testing and using pesticides [12]. The seeds were treated as follows: Trichodermin 2 L/t, Planriz $1 \mathrm{~L} / \mathrm{t}$, Gaubsin $1 \mathrm{~L} / \mathrm{t}$, and RaksilUltra,FS $0.2 \mathrm{~L} / \mathrm{t}$.

\section{Results and Discussion}

The teliospores of hard smut (Tilletia ssp.) and the signs of fusariosis (Fusarium ssp.) were found during phytostudy of winter wheat seeds. Germination of seeds in a wet chamber showed that laboratory germination of 'Levada' variety was $85.5-91.5 \%$ and 'Podolyanka' variety was $84.5-88 \%$, which was lower than the standard germination. It can be explained by a rather high level of contamination with pathogenic organisms. In $2016,38 \%$ of seeds of 'Podolyanka' variety had characteristics indicating damage such as dark gray, white, gray-blue and brown deposits. In 2017 and 2018, seed samples had a slightly decreased rate of damage of 32-33\%. 'Levada' variety showed a similar pattern: the rate of contamination was the highest in 2016 (25\%) and decreased to $18-20 \%$ in $2017-2018$.

The analysis of species composition of mycoflora of the studied varieties of winter wheat seeds allows to make the conclusion that there is a difference in the spread of the infection over the years (Table 1). It should be noted that microscopy results allowed for identification of fungal etiology of those species that according to a systematic classification belong to mitospore fungi such as Alternaria alternata, Fusarium spp., Cladosporium herbarum, and Bipolaris sorokiniana (Fusarium, Cladosporium and Bipolarisin teleomorph belong tophylum Ascomycota; Tilletia caries belong to Basidiomycota; Mucor spp. to phylum Zygomycota; Penicillium spp. and Aspergillus spp. to phylum Ascomycota). The "primary" (field) and "secondary" (storage) infections were noted among seed infections. The first group included fungi that colonize wheat during the ripening period and whose spores reach the seeds during threshing. They are Alternaria alternata, Fusarium spp., Cladosporium herbarum, Bipolaris sorokiniana, and Tilletia caries. In the second group we included representatives of the saprophytic flora that develop on the seeds during storage. The examples include Mucor spp., Penicillium spp., and Aspergillus spp.

Fungi of Alternaria genus were predominant on winter wheat seeds of 'Levada' variety. Their prevalence has changed over the years. The maximum level of contamination $(13.5 \%)$ was recorded in 2016. It decreased to $10 \%$ in 2018 . The lowest level of contamination $(6.8 \%)$ was recorded in 2017. Fungi of genus Fusarium pose danger to the development of seedlings and the primary root system. In 2018 , they were detected in $2 \%$ of the seeds. During the rest of the years of research, their level decreased to $0.5-1.5 \%$. The teliospores of hard smut pathogen were also isolated, but only in 2017 and 2018 (1$1.5 \%$ ). They did not affect germination. However, they posed a risk of infection of seedlings in the soil. In 2016 and 2017, spores of the saprophytic fungus Cladosporium herbarum $(2,5 \%)$ were found on the seeds. They may reduce the quality of the crops under certain conditions. It is quite often found on the overripe cereals in a form of olive mold. 
Among secondary infections Mucor (1.5-4\%) and Penicillium (0.5-1.5\%) fungi were commonly found. In 2018, conidial sporulation of fungi of Aspergillus genus (1\%) was found.

Table 1. Species composition of mycoflora of winter wheat seeds

\begin{tabular}{|l|c|c|c|c|c|c|}
\hline \multirow{2}{*}{$\begin{array}{l}\text { Micromycetes } \\
\text { composition }\end{array}$} & \multicolumn{7}{|c|}{ 'Levada' variety } & \multicolumn{7}{c|}{ 'Podolyanka' variety } \\
\cline { 2 - 7 } & 2016 & 2017 & 2018 & 2016 & 2017 & 2018 \\
\cline { 2 - 7 } & 13.5 & 6.8 & 10 & 18.3 & 18 & 19.5 \\
\hline Alternaria alternata & - & 1,5 & 1 & - & 1.5 & 2 \\
\hline Tilletia caries & 2 & 1.5 & 0.5 & 2.2 & 3.5 & 1.5 \\
\hline Fusarium spp. & 2.5 & 2.5 & - & 3.5 & 1.5 & - \\
\hline Cladosporium herbarum & 4.5 & 4.8 & 1 & 1.5 & 2 & 1.5 \\
\hline Bipolaris sorokiniana & 1.5 & 1.5 & 4 & 12 & 5 & 5 \\
\hline Mucor spp. & 1 & 1.5 & 0.5 & 0.5 & 1.5 & 1 \\
\hline Penicillium spp. & - & - & 1 & - & - & 1.5 \\
\hline Aspergillus spp. & & & & & & 5 \\
\hline
\end{tabular}

The analysis of the species composition of mycoflora of the seeds of 'Podolyanka' variety was shown to be identical to 'Levada' variety, except the difference in the frequency of manifestation. The fungi of the genus Alternaria (18.0-19.5\%) remained dominant. In 2018, the maximum level of contamination was recorded (19.5\%). It was almost twice as high as for 'Levada' variety. The incidence of fusariosis was $1.5-3.5 \%$ but the dynamics of distribution over the years in both varieties was similar. In 2016, a high level of infection with Cladosporium (3.5\%) was noted while no infection was recorded in 2018. In 2017 and 2018, microscopic examination of the seeds of 'Levada' and 'Podolyanka' varieties revealed the teliospores of hard smut Tilletia caries with a frequency of occurrence of $1.5 \%$ and $2 \%$, respectively. A similar species composition of the storage infection on the seeds of the varieties that were studied should be noted. Fungi of the genus Mucor were dominant (5-12\%) with the highest incidence level in 2016. Almost the same level of incidence of Penicillium (0.5-5\%) was observed over the years, while fungi of the genus Aspergillus (1.5\%) were found on seeds only in 2018.

It is noteworthy that micromycetes of genera Alternaria, Fusarium, Bipolaris and Tilletia that are dangerous to white wheat were found on the seeds. The representatives of the first three genera can cause a decrease in field germination and cause roots of the plants to rot during further development, and the pathogen of hard smut can infect the seedlings during seed germination.

To determine the level of the infection of the seeds, the print method was used which more accurately diagnosed the level of contamination of the seeds (Tables 2 and 3). In this case, fungi with distinct morphological characteristics of the genera Alternaria (clubshaped spores, multicellular, dark-colored), Fusarium (sickle-shaped multicellular), Cladosporium (mono- and bicellular, ellipsoid or angular), and Tilletia caries (round, darkbrown witha mesh-like design) were identified.

Table2. The rate of infection of winter wheat seeds of 'Levada' variety

\begin{tabular}{|l|c|c|c|c|c|c|}
\hline \multirow{2}{*}{$\begin{array}{c}\text { Genus of } \\
\text { micromycetes }\end{array}$} & \multicolumn{3}{|c|}{ \% of infected seeds } & \multicolumn{3}{c|}{$\begin{array}{c}\text { The degree of infection of seeds, } \\
\text { spores per 1 seed }\end{array}$} \\
\cline { 2 - 7 } & 2016 & 2017 & 2018 & 2016 & 2017 & 2018 \\
\hline Alternaria & 24.5 & 15.5 & 20 & 10 & 5.1 & 8.3 \\
Cladosporium & 10 & 12 & - & 1.5 & 2 & - \\
Fusarium & 3 & 1.5 & - & 2 & 0.5 & - \\
Tilletia caries & 10 & 20 & 8.5 & 2.2 & 7.3 & 5.5 \\
\hline
\end{tabular}


First of all, we were interested in the possibility of determining the level of contamination by the pathogen of hard smut. Studies show a high rate of infection of the seeds of 'Levada' (8.5-20\%) and 'Podolyanka' (8-24.5\%) varieties with Tilletia caries and a high degree of seed infection: $2.2-7.3$ spores per 1 seed in 'Levada' variety, and 1.29.3 spores per 1 seed in Podolynaka variety. The maximum values were recorded in 2017. A rather high contamination of the seeds with Alternaria spores was noted. The 'Levada' variety had the rate of infection of $15.5-24.5 \%$ and the degree of the seed infection of 5.110 spores per 1 seed. The 'Podolyanka' variety had the rate of infection of $30.5-34.0 \%$ and the degree of the seed infection of 9.2-16.5 spores per 1 seed, respectively. In 2017, the lowest seed contamination was observed. The rate of infection with spores of the fungus Cladosporium was $10-12 \%$ in the seeds of 'Levada' variety and $9-15.5 \%$ in the seeds of 'Podolyanka' variety. At the same time, the average of 1.5-2 and 1.8-2.5 spores per 1 seed were observed on the seeds, respectively. In 2018, no pathogens were found. The lowest rate of seed infection was caused by Fusarium spores: $1.5-3 \%$ in 'Levada' variety and $0.5-$ $3.5 \%$ in 'Podolyanka' variety. In 2018, the seeds were least infected.

Table 3. The rate of infection of winter wheat seeds of 'Podolyanka' variety

\begin{tabular}{|l|c|c|c|c|c|c|}
\hline \multirow{2}{*}{$\begin{array}{l}\text { Genus of } \\
\text { micromycetes }\end{array}$} & \multicolumn{3}{|c|}{ \% of infected seeds } & \multicolumn{3}{c|}{$\begin{array}{c}\text { The degree of infection of seeds, } \\
\text { spores per 1 seed }\end{array}$} \\
\cline { 2 - 7 } & 2016 & 2017 & 2018 & 2016 & 2017 & 2018 \\
\hline Alternaria & 31.5 & 30.5 & 34 & 9.2 & 15.2 & 16.5 \\
Cladosporium & 15.5 & 9 & - & 2.5 & 1.8 & - \\
Fusarium & 2.2 & 3.5 & 0.5 & 1 & 1.2 & 0.1 \\
Tilletia caries & 8 & 24.5 & 22 & 1.2 & 8.5 & 9.3 \\
\hline
\end{tabular}

Because the revealed pathogenic complex poses a threat to the germination and further growth of the seeds and also considering the high relevance of the biologization of agriculture, we studied the possibility of improving the phytosanitary state of the studied seeds with biological fungicides. The laboratory germination, the infection rate with pathogens, and pathogen species identification were performed in a wet chamber on the eighth day after the seeds were treated with biological preparations.

The data presented in Table 4 indicate that the treatment with biofungicides did not significantly affect the laboratory germination of the seeds. A positive trend was observed when treated with a chemical agent Raksil Ultra, FS. A tendency to a decrease in the level of infection of the seeds is observed with the use of biofungicides while the treatment with Raksil Ultra, FS practically completely disinfects the seeds $(0.5-1.0 \%)$. Thus, the wet chamber method was not effective for assessing the effectiveness of the biological products.

Table 4. The effects of seed treatment with biofungicides on certain sowing characteristics of winter wheat (average values for 2016 to 2018 years)

\begin{tabular}{|c|c|c|c|c|c|c|}
\hline \multirow{3}{*}{ Treatment } & \multicolumn{3}{|c|}{ 'Levada' } & \multicolumn{3}{|c|}{ 'Podolyanka' } \\
\hline & \multicolumn{2}{|c|}{$\begin{array}{l}\text { Laboratory } \\
\text { germination }\end{array}$} & \multirow{2}{*}{$\begin{array}{c}\text { The rate of } \\
\text { infection, } \\
\%\end{array}$} & \multicolumn{2}{|c|}{$\begin{array}{l}\text { Laboratory } \\
\text { germination }\end{array}$} & \multirow{2}{*}{$\begin{array}{c}\text { The rate of } \\
\text { infection, } \\
\%\end{array}$} \\
\hline & $\%$ & $\begin{array}{l}+ \text { - vs } \\
\text { control }\end{array}$ & & $\%$ & $\begin{array}{l}+ \text { - vs } \\
\text { control }\end{array}$ & \\
\hline Control (treatment with water) & 90 & - & 19.5 & 87.5 & - & 27.5 \\
\hline Control (Raksil Ultra, FS) & 94 & +4 & 0.5 & 91.5 & +4 & 1 \\
\hline Gaubsin & 92 & +2 & 18.5 & 89.5 & +2 & 25 \\
\hline Planriz & 91.5 & +1.5 & 20 & 89.5 & +2 & 26.5 \\
\hline Trichodermin & 92 & +2 & 17 & 92 & +4.5 & 21.5 \\
\hline
\end{tabular}




\begin{tabular}{|l|l|l|l|l|l|l|}
\hline Lsd, 0,05 & 6.2 & & 3.5 & 7.5 & & 2.9 \\
\hline
\end{tabular}

The information presented above confirms [13] that soil or a substrate that performs its function is needed for the action of microorganisms to be observed. Figures 1 and 2 present data on the study of the action of biofungicides used during cultivation of treated seeds on the substrate. The overall trend of the positive effects of biological preparations on the morphometric parameters of winter wheat plants should be noted. The height of plants of 'Levada' variety increased by $66.7-100 \%$ and the length of the root system increased by 151.1-183\% compared to the control (Figure 1).

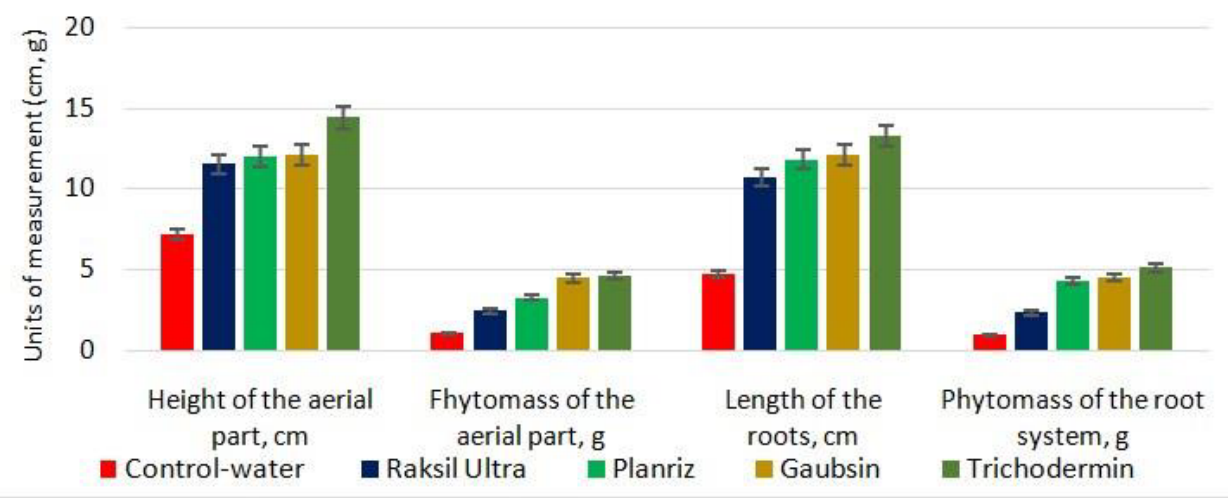

Fig. 1. The effects of biofungicidal preparations on morphometric parameters of winter wheat, 'Levada' variety (average values for 2016 to 2018 years)

At the same time, phytomass of the aerial part of the plants increased by 3.1-4.4 times and the root system by 4.6-5.5 times. 'Podolyanka' variety had similar findings (Figure 2). The height of the samples treated with biofungicides increased by $67-82.3 \%$ and the length of the roots increased by $112.1-136.2 \%$. The phytomass of the aerial part of the plants increased by 2.7-4.0 times, and the phytomass of the roots increased by 3.4-4.7 times in the treatment group. A steady tendency to increase in these parameters with treatment of seeds with Trichodermin should be noted. It can be explained by the positive effects of Trichoderma ssp. on a plant: the similar tendency occurs during mycorrhization [8]. At the same time, the tendency to a decrease in the development indicators of plants was observed in the group treated with Raksil Ultra, FS, compared to those treated with biofungicides which is associated with inhibition of growth.

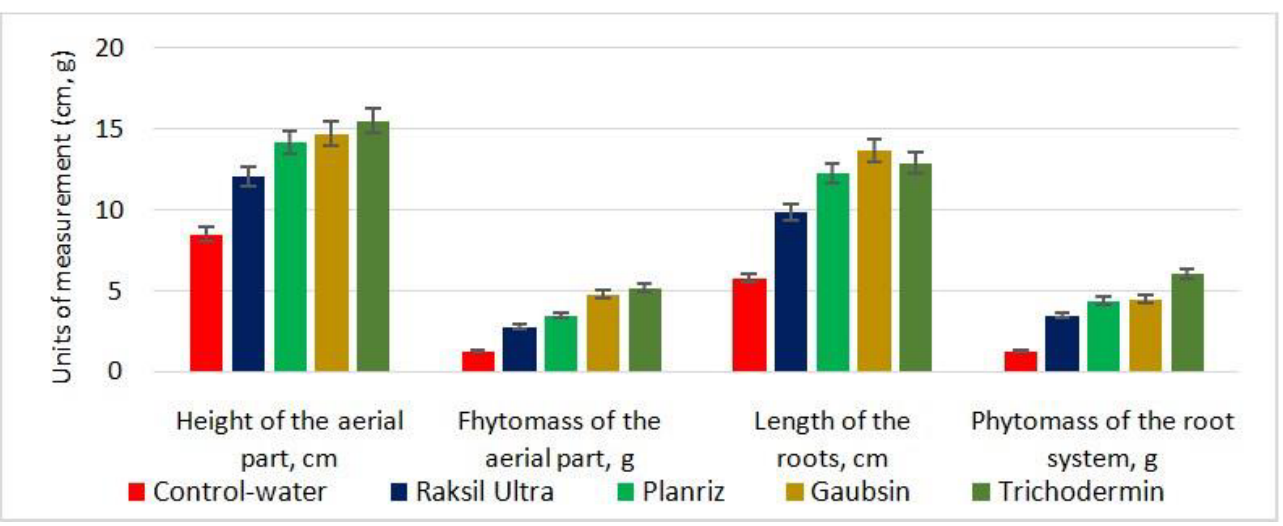


Fig. 2. The effects of biofungicidal preparations on morphometric parameters of winter wheat, 'Podolyanka' variety (average values for 2016 to 2018 years)

\section{Conclusions}

1. As a result of phytostudy of seeds of winter wheat of 'Levada' and 'Podolyanka' varieties by the wet chamber method which was completed in 2016 to 2018 , the pathogens causing infections of fungal etiology were determined. Among them were Alternaria alternata (infection rate, 6.8-19.5\%), Tilletia caries (1-2\%), Fusarium spp. (0.5-3.5\%), Cladosporium herbarum (1.5-3.5\%), Bipolaris sorokiniana (1-4.8\%), Mucor spp. (1.5$12 \%)$, Penicillium spp. (0.5-1.5\%), Aspergillus spp. (1-1.5\%). The method of prints was more effective for identification of the causative agents of hard smut. The seeds of 'Levada' variety had contamination of $8.5-20 \%$, the infection rate was $2.2-7.3$ spores per seed; 'Podolyanka' variety had contamination of $8-24.5 \%$ and the infection rate of $1.2-$ 9.3 spores per seed, respectively.

2. As a results, of treatment of seeds with biofungicides Gaubsin, Planriz and Trichodermin and further germination under laboratory conditions, there was a tendency to increase laboratory germination and reduce infection rate with micromycetes within the confidence limits of the experiment. At the same time, growing treated seeds on a substrate proves the positive effect of biological fungicides on plant morphometric parameters in the initial stages of ontogenesis. Their height increased by 1.6-2.0 times, and the root length increase by $2.1-2.8$ times. The phytomass of the aerial parts of the experimental plants became 2.7-4.4 times greater, and the root system became 3.4-5.5 times greater. Trichodermin was shown to be a more effective preparation.

3 . In the conditions of organic agricultural production, the treatment of winter wheat seeds with biological fungicides should become an important element of agricultural technology because it affects not only the quantitative and qualitative parameters of seed contamination with mycoflora but also has a positive effect on plant growth.

\section{References}

1. R. R. Azizbekyan, Appl. Biochem. and Microb., 54, 8 (2019) https://doi.org/10.1134/S0003683819080027

2. M. Grover, L. Nain, S. B. Singh, A.K.Saxena, Curr. Microbiol, 60, 99-106 (2010) https://doi.org/10.1007/s00284-009-9508-6

3. K. Nagórska, M. Bikowski, M. Obuchowski, ActaBioch. Pol, 54, 3 (2007) PMID: 17882321

4. S. V. Pospelov, G. D. Pospelova, V. V. Onipko, M. V. Semenko, Natural Remedies for Pest, Disease and Weed Control 91-106 (2019) https://doi.org/10.1016/B978-0-12-819304-4.00008-7

5. C. R. Howell, USDA/ARS South. Plains Agr. Res. Center, 87, 1 (2003) https://apsjournals.apsnet.org/doi/pdf/10.1094/PDIS.2003.87.1.4

6. A. B. Kovalyshyn, Karantyn i zakhyst roslyn, 1, 6-8 (2012)

7. T. Paulitz, B. Nowak-Thompson, P. Gamard, E. Tsang, J. Loper, J. of Chem. Eco., 26, 6 (2000) https://doi.org/10.1023/A:1005595927521

8. G. E. Harman, Phytopathology, 96, 2 (2006)

9. R. V. Gupta, M. Schmoll, A. Herrera-Estrella, R. S. Upadhyay, I. Druzhinina, M. G. Tuohy Molecular Tools for Strain smprovement of Trichoderma spp. 179-191 (2011) https://doi.org/10.1016/B978-0-444-59576-8.00012-6

10. Nasinnia silskohospodarskykh kultur. Metody vyznachennia yakosti: DSTU, 4138-2002 (2003)

11. Nasinnia silskohospodarskykh kultur. Sortovi ta posivniiakosti. Tekhnichni umovy DSTU, 224093 (1994)

12. Metodyky vyprobuvannia i zastosuvannia pestytsydiv (2001) 
13. A. D. Pospelova, O. V. Barabolia, O. O. Morozova, Bull. of Poltava st. agr. acad., 4 (2018) https://doi.org/10.31210/visnyk2018.04.05 